\title{
HUBUNGAN STATUS GIZI DENGAN PERKEMBANGAN ANAK USIA TOODLER(1-3 TAHUN) DI DESA BANGKAL KECAMATAN KOTA SUMENEP KABUPATEN SUMENEP TAHUN 2019
}

\author{
Relationship Of Nutritional Status With Development Of Age Toodler Children (1-3 Years) \\ In Bangkal Village, Sumenep City Sumenep District, 2019
}

\author{
Eva Nurhidayati; Dian Permatasari Program Studi Kebidanan Unija Sumenep \\ Email ; evanurhidayati06@gmail.com; dianpfik@wiraraja.ac.id
}

\begin{abstract}
Abstrak
Pada umumnya usia 1-3 tahun pertama kehidupan akan menentukan kualitas hidup anak di kemudian hari. Pertumbuhan optimal dan perkembangan bertujuan untuk membuat anak tidak hanya tumbuh secara fisik, tetapi juga memiliki kualitas hidup yang baik. Status gizi yang baik memainkan peran dalam membantu perkembangan anak. Masalah dalam penelitian ini terdapat $2(20 \%)$ anak yang mengalami penyimpangan dari yang seharusnya tidak ada. Tujuan dalam penelitian ini untuk mengetahui hubungan status gizi dengan perkembangan anak usia toodler (1-3 tahun) di desa Bangkal Kecamatan Kota Sumenep.

Desain penelitian yang digunakan adalah analitik dengan dengan rancangan cross sectional. Populasi yang digunakan dalam penelitian ini yaitu sebanyak 38 anak dan sampelnya yaitu sebanyak 35 anak dengan menggunakan KPSP dan kuesioner. Teknik sampel yang digunakan yaitu simple random sampling. Sedangkan analisis data menggunakan uji spearman.

Hasil penelitian menunjukkan bahwa sebagian besar $(65,7 \%)$ anak memiliki status gizi normal, dan sebagian besar $(51,4 \%)$ anak mengalami perkembangan yang sesuai. Dari hasil uji statistik menunjukkan $(\rho=$ $0,664>\alpha=0,05)$ sehingga $\mathrm{H}_{1}$ ditolak artinya tidak ada hubungan antara status gizi dengan perkembangan.

Kesimpulan dalam penelitian ini adalah status gizi tidak memiliki korelasi dengan perkembangan anak yang dimana status gizi anak yang kurus tidak selamanya menyebabkan perkembangan anak menjadi menyimpang dan sebaliknya status gizi anak yang normal tidak selamanya menyebabkan perkembangan anak menjadi sesuai, kemungkinan ada faktor lain yang dapat mempengaruhi perkembangan pada anak.
\end{abstract}

Kata Kunci : Perkembangan Anak, Status Gizi, Toodler

\begin{abstract}
In general, the first 1-3 years of life will determine the quality of life of children in the future. Optimal growth and development aims to make children not only grow physically, but also have a good quality of life. Good nutritional status plays a role in helping children develop. The problem in this study is that there are $2(20 \%)$ children who experience deviations from what should not be there. The purpose of this study was to determine the relationship of nutritional status with child development toodler age (1-3 years) in the village of Bangkal, Sumenep City District.

The research design used was analytical with a cross sectional design. The population used in this study were 38 children and the sample was 35 children using KPSP and questionnaires. The sample technique used is simple random sampling. While the data analysis used the Spearman test.

The results showed that most $(65.7 \%)$ children had normal nutritional status, and the majority (51.4\%) of children experienced appropriate development. From the results of statistical tests show $(\rho=0.664 \alpha$ $\alpha=0.05)$ so that $\mathrm{H} 1$ is rejected, meaning there is no relationship between nutritional status and development.

The conclusion in this study is that nutritional status does not correlate with the development of children, where the nutritional status of thin children does not always cause the development of children to deviate and vice versa the normal nutritional status of children does not always make children's development appropriate, there may be other factors that can influence development in children.
\end{abstract}

Keywords: Child Development, Nutritional Status, Toodler 


\section{PENDAHULUAN}

Perkembangan awal anak penting dijadikan perhatian khusus, sebab akan menentukan tahap perkembangan selanjutnya. Perkembangan motorik anak lebih cepat berjalan pada masa anak usia dini sering disebut dengan istilah "golden age" atau masa periode emas, meskipun pertumbuhan fisik anak relatif lebih lambat dibandingkan dengan masa bayi. Anak sering mengalami penurunan nafsu makan sehingga tampak langsing, berotot dan anak mulai belajar berjalan (Nusalam, M.Nurs.dkk, 2010:37). Pencapaian suatu kemampuan atau perkembangan setiap anak tidak sama, karena setiap individu memiliki kemampuan atau perkembangan yang berbeda. Makanan yang bergizi dan seimbang serta stimulasi yang intensif sangat dibutuhkan untuk pertumbuhan dan perkembangan tersebut. Jika perkembangan anak luput dari perhatian orang tua maka anak akan berkembang seadanya sesuai dengan yang hadir dan menghampiri mereka. Berdasarkan data di Puskesmas Pamolokan yang mengalami cakupan terendah dalam pemantauan tumbuh kembang adalah di Desa Bangkal yaitu hanya terdapat $81,8 \%$ balita yang dapat dipantau dari jumlah 110 balita yang ada. Dengan cara pengamatan sementara yang dilakukan peneliti pada tanggal 11 januari 2019 terhadap 10 orang anak 1-3 Tahun di Desa Bangkal diperoleh data, bahwa dari $2(20 \%)$ anak mengalami penyimpangan, $5(50 \%)$ anak mengalami perkembangan yang meragukan dan $3(30 \%)$ anak yang tidak mengalami keterlambatan perkembangan / normal. Jadi masalah dalam penelitian ini adalah terdapatnya penyimpangan tumbuh kembang usia toodler (1-3 Tahun) yaitu 2 (20\%) di Desa Bangkal Kecamatan Kota Sumenep Tahun 2019.

$$
\text { Sedangkan data berdasarkan }
$$

RISKESDAS 2018 Indikator untuk menentukan anak yang harus dirawat dalam manajemen gizi buruk adalah keadaan sangat kurus yaitu anak dengan nilai Zscore <-3,0 SD. Prevalensi sangat kurus secara nasional tahun 2013 masih cukup tinggi yaitu 5,3 persen, terdapat penurunan dibandingkan tahun $2010(6,0 \%)$ dan tahun $2007(6,2 \%)$. Demikian pula halnya dengan prevalensi kurus sebesar $6,8 \%$ juga menunjukkan adanya penurunan dari 7,3\% (tahun 2016) dan 7,4\% (tahun 2017). Secara keseluruhan prevalensi anak balita kurus dan sangat kurus menurun dari 13,6\% pada tahun 2017 menjadi 12,1\% pada tahun 2018. Pada tahun 2018 prevalensi gemuk secara nasional di Indonesia adalah $11,9 \%$, yang menunjukkan terjadi penurunan dari $14,0 \%$ pada tahun 2016. Terdapat 12 provinsi yang memiliki masalah anak gemuk di atas angka nasional.

Masalah kesehatan masyarakat sudah dianggap serius bila prevalensi kurus antara 10,0\%-14,0\% dan dianggap kritis bila $\geq 15,0 \%$ (WHO 2010). Pada tahun 2018, secara nasional prevalensi kurus pada anak balita masih $12,1 \%$, yang artinya. masalah kurus di Indonesia masih merupakan masalah kesehatan masyarakat yang serius.

Berdasarkan data hasil kegiatan

Pemantauan Status Gizi (PSG) dengan indikator $\mathrm{BB} / \mathrm{TB}$ yang diperoleh dari Dinas Kesehatan Kabupaten Sumenep didapatkan bahwa pada tahun 2018 dari 27 kecamatan, terdapat 4 kriteria yang menjadi penilaian dalam melakukan hasil kegiatan pemantauan status gizi meliputi sangat kurus, kurus, normal, gemuk.

Dengan adanya deteksi secara dini maka akan lebih gampang untuk mengetahui adanya penyimpangan atau tidak secara dini, jika di suatu Desa tersebut terdapat penyimpangan perkembangan maka perlu segara ditangani agar tidak berdampak dikemudian hari. Maka peneliti ingin mengetahui hubungan status gizi dengan perkembangan pada anak usia toodler (1-3 tahun). Dengan demikian kita dapat mengetahui apakah ada hubungan status gizi anak dengan perkembangan anak secara optimal atau tidak.

\section{METODE PENELTIAN}

Dalam penelitian ini penulis menggunakan metode penelitian analitic correlational. Pendekatan yang digunakan adalah dengan studi cross sectional.

Populasi dalam penelitian ini yaitu seluruh ibu beserta anak usia Toodler (1-3 Tahun) di Desa Bangkal Kecamatan Kota Sumenep yaitu sebanyak 38 responden.

Teknik sampling menggunakan probability sampling dengan jenis Total Sampling. Sampel penelitian ini seluruh ibu beserta anak usia Toodler (1-3 Tahun) di Desa Bangkal Kecamatan Kota Sumenep yaitu sebanyak 38 responden.

Variabel independen dalam penelitian ini yaitu status gizi. Variabel dependen pada 
peneletian ini perkembangan anak usia toodler (1-3 tahun).

Instrumen yang akan digunakan peneliti untuk mengetahui apakah ada korelasi tentang status gizi dengan perkembangan anak usia toodler (1-3 tahun) menggunakan lembar kuesioner.

Dalam analisis data menggunakan uji korelasi Rank Spearman dengan menggunakan program SPSS 20 for windows dengan tingkat kemaknaan $\square=0,05$ artinya bila nilai $\mathrm{P} \leq \square$ maka $\mathrm{H}_{0}$ ditolak.

\section{HASIL PENELITIAN}

\section{Data Umum}

\section{1) Usia Toodler}

Tabel 1. Distribusi Responden Berdasarkan Usia Toodler di Desa Bangkal Kecamatan Kota Kabupaten Sumenep Tahun 2019

\begin{tabular}{cccc}
\hline & & \multicolumn{2}{c}{ Responden } \\
\cline { 3 - 4 } No & Usia & \multicolumn{2}{c}{$\begin{array}{c}\text { Presentase } \\
(\%)\end{array}$} \\
\hline 1. & $12-15$ & 6 & 17,1 \\
2. & $16-19$ & 7 & 20 \\
3. & $20-23$ & 8 & 22,9 \\
4. & $24-27$ & 4 & 11,4 \\
5. & $28-31$ & 2 & 5,7 \\
6. & $32-36$ & 8 & 22,9 \\
\hline \multicolumn{2}{c}{ Jumlah } & 35 & 100 \\
\hline
\end{tabular}

Sumber : data primer tahun 2019

Berdasarkan tabel 1 diketahui bahwa sebagian kecil responden memiliki usia 20-23 bulan dan 32-36 bulan.

\section{2) Pendidikan Ibu}

Tabel 2. Distribusi Responden Berdasarkan Pendidikan Ibu Yang Mempunyai Anak Usia Toodler di Desa Bangkal Kecamatan Kota Kabupaten Sumenep Tahun 2019

\begin{tabular}{llcc}
\hline & & \multicolumn{2}{c}{ Responden } \\
\cline { 3 - 4 } No. & Pendidikan Ibu & Frekuensi & $\begin{array}{c}\text { Persen- } \\
\text { tase } \\
(\%)\end{array}$ \\
\hline 1 & SD & 18 & 51,4 \\
2 & SMP & 8 & 22,8 \\
3 & SMA & 6 & 17,1 \\
4 & Perguruan Tinggi & 3 & 8,6 \\
\hline \multicolumn{2}{c}{ Jumlah } & 35 & 100 \\
\hline
\end{tabular}

Sumber : data primer tahun 2019

Berdasarkan tabel 2 diketahui bahwa sebagian besar responden pendidikan terakhir adalah SD.

\section{3) Pekerjaan Ibu}

Tabel 3 Distribusi Responden Berdasarkan Pekerjaan Ibu Yang Mempunyai Anak Usia Toodler di Desa Bangkal Kecamatan Kota Kabupaten Sumenep Tahun 2019

\begin{tabular}{clcc}
\hline No & Pekerjaan Ibu & Responden \\
\cline { 3 - 4 } & Frekuensi & $\begin{array}{c}\text { Persen- } \\
\text { tase } \\
(\boldsymbol{\%})\end{array}$ \\
\hline 1 & IRT & 9 & 25,7 \\
2 & Petani & 17 & 48,6 \\
3 & Swasta/pedagang & 6 & 17,1 \\
4 & Pegawai Negeri & 3 & 8,6 \\
\hline & Jumlah & 35 & 100 \\
\hline
\end{tabular}

Sumber : data primer tahun 2019

Berdasarkan tabel 3 diketahui bahwa hampir setengahnya responden bekerja sebagai petani. 


\section{4) Jenis Kelamin Anak}

Tabel 4 Distribusi Responden Jenis Kelamin Anak Usia Toodler di Desa Bangkal Kecamatan Kota Kabupaten Sumenep Tahun 2019

\begin{tabular}{cccc}
\hline & & \multicolumn{2}{c}{ Responden } \\
\cline { 3 - 4 } No & $\begin{array}{c}\text { Jenis } \\
\text { Kelamin }\end{array}$ & $\begin{array}{c}\text { Freku } \\
\text { ensi }\end{array}$ & $\begin{array}{c}\text { Perse } \\
\text { ntase } \\
(\mathbf{\%})\end{array}$ \\
\hline 1 & Laki - Laki & 19 & 54,3 \\
2 & Perempuan & 16 & 45,7 \\
\hline & Jumlah & 35 & 100 \\
\hline
\end{tabular}

Sumber : data primer tahun 2019 Berdasarkan tabel 4 diketahui bahwa sebagian besar responden berjenis kelamin laki-laki.

\section{Data Khusus}

\section{1) Status Gizi Anak}

Tabel 5 Distribusi Responden Berdasarkan Status Gizi Anak Usia Toodler di Desa Bangkal Kecamatan Kota Kabupaten Sumenep Tahun 2019

\begin{tabular}{|c|c|c|c|}
\hline \multirow[b]{2}{*}{ No } & \multirow[b]{2}{*}{ Status Gizi } & \multicolumn{2}{|c|}{ Responden } \\
\hline & & $\begin{array}{c}\text { Frekue } \\
\text { nsi }\end{array}$ & $\begin{array}{c}\text { Perse } \\
\text { n-tase } \\
(\%)\end{array}$ \\
\hline 1 & Sangat Kurus & 0 & 0 \\
\hline 2 & Kurus & 10 & 28,6 \\
\hline 3 & Gemuk & 2 & 5,7 \\
\hline \multirow[t]{2}{*}{4} & Normal & 23 & 65,7 \\
\hline & Jumlah & 35 & 100 \\
\hline
\end{tabular}

Sumber : data primer tahun 2019

Berdasarkan tabel 5 diketahui bahwa sebagian besar responden berstatus gizi normal.

\section{2) Perkembangan Anak}

Tabel 6 Distribusi Responden Berdasarkan Perkembangan Anak Usia Toodler di Desa Bangkal Kecamatan Kota Kabupaten Sumenep Tahun 2019

\begin{tabular}{|c|c|c|c|}
\hline \multirow[b]{2}{*}{ No } & \multirow[b]{2}{*}{ Perkembangan } & \multicolumn{2}{|c|}{ Responden } \\
\hline & & $\begin{array}{c}\text { Freku } \\
\text { ensi }\end{array}$ & $\begin{array}{l}\text { Persent } \\
\text { ase }(\%)\end{array}$ \\
\hline 1 & $\begin{array}{c}\text { Ada } \\
\text { Penyimpangan }\end{array}$ & 2 & 5,7 \\
\hline 2 & Meragukan & 15 & 42,8 \\
\hline 3 & Sesuai & 18 & 51,4 \\
\hline & Jumlah & 35 & 100 \\
\hline
\end{tabular}

Sumber : data primer tahun 2019

Berdasarkan tabel 6 diketahui bahwa sebagian besar responden mengalami perkembangan yang sesuai.

\section{3) Analisa Hubungan Status Gizi dengan Perkembangan Anak Usia Toodler (1-3 tahun) Di Desa Bangkal Kecamatan Kota Sumenep.}

Tabel 7 Hasil Tabulasi Silang

\begin{tabular}{|c|c|c|c|c|c|c|c|c|c|}
\hline \multirow{3}{*}{$\begin{array}{l}\mathbf{N} \\
\mathbf{0}\end{array}$} & \multirow{3}{*}{$\begin{array}{c}\text { Status } \\
\text { Gizi }\end{array}$} & \multicolumn{6}{|c|}{ Perkembangan Anak } & \multirow{2}{*}{\multicolumn{2}{|c|}{ Total }} \\
\hline & & \multicolumn{2}{|c|}{ Sesuai } & \multicolumn{2}{|c|}{$\begin{array}{c}\text { Meragu } \\
\text { kan }\end{array}$} & \multicolumn{2}{|c|}{$\begin{array}{c}\text { Ada } \\
\text { Penyimpa } \\
\text { ngan }\end{array}$} & & \\
\hline & & $\mathrm{n}$ & $\%$ & $\mathrm{n}$ & $\%$ & $\mathrm{n}$ & $\%$ & $\mathrm{n}$ & $\%$ \\
\hline 1. & $\begin{array}{l}\text { Sangat } \\
\text { Kurus }\end{array}$ & 0 & 0 & 0 & 0 & 0 & 0 & 0 & 100 \\
\hline 2. & Kurus & 6 & 60 & 3 & 30 & 1 & 10 & 10 & 100 \\
\hline 3. & Gemuk & 1 & 50 & 1 & 50 & 0 & 0 & 2 & 100 \\
\hline 4. & Normal & 11 & $\begin{array}{r}47 \\
, 8\end{array}$ & 11 & $\begin{array}{r}47 \\
, 8\end{array}$ & 1 & 4,3 & 23 & 100 \\
\hline & Jumlah & 18 & $\begin{array}{l}51 \\
, 4\end{array}$ & 15 & $\begin{array}{r}42 \\
, 9\end{array}$ & 2 & 5,7 & 35 & 100 \\
\hline
\end{tabular}

\section{Sumber : data primer tahun 2019}

Berdasarkan tabel 7 menunjukkan bahwa pada kelompok responden yang memiliki status gizi kurus sebagian besar (60\%) mengalami perkembangan yang sesuai dan responden yang memiliki status gizi gemuk setengahnya (50\%) mengalami perkembangan yang sesuai dan meragukan, sedangkan responden 
yang memiliki status gizi normal hampir setengahnya $(47,8 \%)$ mengalami perkembangan yang sesuai dan meragukan.

Hasil uji didapatkan hasil $0,664>0,05$ atau $\rho>\alpha$ maka dapat disimpulkan tidak ada hubungan status gizi dengan perkembangan anak usia Toodler (1-3 tahun) di Desa Bangkal Kecamatan Kota Sumenep Tahun 2019

\section{PEMBAHASAN}

\section{Status Gizi}

Berdasarkan hasil Penelitian diketahui bahwa sebagian besar $(65,7 \%)$ responden mengalami status gizi normal, hampir setengahnya $(28,6 \%)$ responden mengalami status gizi kurus dan sebagian kecil $(5,7 \%)$ responden mengalami status gizi gemuk. Pendidikan ibu sebagian besar $(51,4 \%)$ ibu memiliki pendidikan terakhir adalah SD dan hampir setengahnya $(48,6 \%)$ ibu bekerja sebagai petani.

Menurut Anwar (2011), zat-zat gizi yang dikonsumsi batita akan berpengaruh pada status gizi batita. Perbedaan status gizi batita memiliki pengaruh yang berbeda pada setiap perkembangan anak, dimana jika gizi yang dikonsumsi tidak terpenuhi dengan baik maka perkembangan balita akan terhambat. Apabila balita mengalami kekurangan gizi akan berdampak pada keterbatasan pertumbuhan, rentan terhadap infeksi, peradangan kulit dan akhirnya dapat menghambat perkembangan anak meliputi kognitif, motorik, bahasa dan keterampilannya dibandingkan dengan batita yang memiliki status gizi baik. Ada faktorfaktor yang mempengaruhi status gizi anak yang meliputi faktor external (pendapatan, pendidikan, pekerjaan, budaya) dan faktor internal (usia, kondisi fisik, infeksi) (Nursalam, 2011).

Berdasarkan hasil tabulasi silang diketahui bahwa ibu yang berpendidikan SD setengahnya (50\%) mempunyai anak yang status gizinya normal, ibu yang berpendidikan SMP hampir seluruhnya $(87,5 \%)$ mempunyai anak yang status gizinya normal, ibu yang berpendidikan SMA sebagian besar $(66,7 \%)$ anaknya memiliki status gizi normal dan ibu yang berpendidikan PT seluruh anaknya memiliki status gizi normal.

$(100 \%)$

Hal ini menunjukkan bahwa pendidikan dapat menentukan tingkat pengetahuan seseorang, seperti halnya semakin tinggi pendidikan seseorang maka semakin baik pula pengetahuan seseorang. Pendidikan dapat menetukan sikap ibu dalam pemenuhan nutrisi pada anaknya, yang dimana semakin baik pendidikan ibu, makin baik pula status gizi anak dalam pertumbuhannya. Hal tersebut perlu ditingkatkan agar pertumbuhan anak lebih baik dari sebelumnya.

Berdasarkan hasil tabulasi silang diketahui bahwa ibu yang bekerja sebagai IRT hampir seluruhnya $(88,9 \%)$ memiliki anak yang status gizinya normal, ibu yang bekerja sebagai pertani sebagian besar $(52,9 \%)$ anaknya berstatus gizi kurus, ibu yang bekerja sebagai swasta/pedagang hampir seluruhnya $(83,3 \%)$ memiliki anak yang status gizinya normal dan ibu yang bekerja sabagai pegawai negeri seluruhnya (100\%) memiliki anak yang status gizinya normal.

Karakteristik pekerjaan seseorang dapat mencerminkan pendapatan, status sosial, pendidikan, status sosial ekonomi, risiko cedera atau masalah kesehatan dalam suatu kelompok populasi. Pekerjaan juga merupakan suatu determinan risiko dan determinan terpapar yang khusus dalam bidang pekerjaan tertentu serta merupakan prediktor status kesehatan dan kondisi tempat suatu populasi bekerja (Widyastuti, 2005).

Dimana makin tinggi tingkat pendidikan seseorang maka makin mudah dalam memperoleh pekerjaan, sehinggah semakin banyak pula penghasilan yang diperoleh. Hal ini berkaitan dengan pekerjaan ibu sebagai pegawai negeri, dimana semakin tinggi pekerjaan seseorang maka pendapatan yang diperolehnya juga banyak, sedangkan pada ibu yang bekerja sebagai petani juga tidak selamanya mendapatkan pendapatan yang sedikit pula, meskipun sebagian besar anak memiliki status gizi kurus, ini berhubungan dengan status ekonomi seseorang karena status ekonomi seseorang menentukan nilai beli suatu makanan, sehingga ibu cenderung memberikan nutrisi yang baik untuk anaknya, sehingga anak mencapai status gizi yang optimal.

Penelitian oleh Dian Kholika Hamal, M.Kes (2010) yang meneliti mengenai hubungan pendidikan dan pekerjaan orangtua 
serta pola asuh dengan status gizi balita di kota dan kabupaten tangerang, banten. Penelitian menunjukkan hasil uji bivariat menunjukkan secara statistik ada hubungan yang bermakna (p-value < 0.05) antara pendidikan ayah dan status gizi balita, sementara variabel lainnya (pendidikan ibu, pekerjaan ibu dan ayah, rangsangan psikososial, praktik kebersihan/ higiene dan sanitasi, serta perawatan kesehatan balita dalam keadaan sakit) secara statistik tidak menunjukkan adanya hubungan yang bermakna ( $p$-value $\geq 0.05$ ) terhadap status gizi balita.

Berdasarkan kondisi dilapangan, diketahui pendidikan ibu sebagian besar adalah SD. Jika dilihat secara deskriptif dapat diketahui bahwa ada hal yang bertolak belakang, dimana seperti diketahui bahwa status gizi batita yang diteliti sebagian besar adalah normal, tetapi sebagian besar pendidikan ibu adalah SD. Tingkat pendidikan tidak selamanya mempengaruhi status gizi anak, hal ini dapat disebabkan oleh beberapa hal diantaranya pengalaman Orang Tua dan informasi yang diperolehnya.

\section{Perkembangan Anak Usia 1-3 tahun}

Berdasarkan data hasil penelitian diketahui bahwa dari 35 Anak sebagian besar $(51,4 \%)$ anak responden memiliki perkembangan yang sesuai, hampir setengahnya $(42,8 \%)$ anak mengalami perkembangan yang meragukan dan sebagian kecil $(5,7 \%)$ anak mengalami penyimpangan.

Berdasarkan hasil tabulasi silang diketahui bahwa ibu yang berpendidikan SD sebagian besar $(55,6 \%)$ mempunyai anak yang perkembangannya sesuai, ibu yang berpendidikan SMP sebagian besar $(62,5 \%)$ mempunyai anak yang perkembangannya meragukan, ibu yang berpendidikan SMA sebagian besar $(66,7 \%)$ mempunyai anak yang perkembangannya meragukan dan ibu yang berpendidikan PT seluruhnya (100\%) mempunyai anak yang perkembangannya sesuai.

Menurut Nursalam (2011) bahwa semakin tinggi pendidikan sesorang, maka semakin mudah menerima informasi sehingga makin banyak pula pengetahuan yang dimiliki. Responden yang berpendidikan tinggi akan mudah menyerap informasi sehingga ilmu pengetahuan yang dimiliki lebih tinggi namun sebaliknya yang berpendidikan rendah akan mengalami hambatan dalam menyerap informasi sehingga ilmu yang dimiliki juga lebih rendah yang berdampak pada kehidupannya.

Berdasarkan uraian diatas, semakin tinggi pendidikan maka semakin baik pula dalam mengaplikasikan materi dalam perkembangan batita yang diperoleh ibu yang berpendidikan tinggi akan lebih baik dalam mengasah perkembangan batita dibandingkan dengan ibu yang berpendidikan rendah. Namun hal ini tidak sesuai bagi ibu yang berpendidikan SD, karena ibu yang berpendidikan SD mempunyai batita yang sebagian besar perkembangannya sesuai, hal ini mungkin terjadi karena ibu mempunyai pengetahuan yang baik, yang diperoleh dari pengalaman dan informasi yang didapatnya dari penyuluhan yang didapatnya di posyandu.

Untuk meningkatkan atau memperbaiki perkembangan batita agar perkembangan batita sesuai dengan usianya, maka stimulasi harus diberikan pada batita dan untuk memberikan stimulasi orang tua atau pengasuh harus mengetahui semua aspek-aspek, pemenuhan kebutuhan dasar tentang perkembangan pada batita. Oleh karena itu pengetahuan masyarakat harus ditingkatkan tentang perkembangan melalui sosialisasi tenaga kesehatan dan kader kesehatan serta melakukan pemantauan dan pemeriksaan perkembangan.

Berdasarkan hasil crosstabulasi diketahui bahwa ibu yang bekerja sebagai IRT sebagian besar $(66,7 \%)$ mempunyai anak yang perkembangannya sesuai, ibu yang bekerja sebagai pertani sebagian besar $(52,9 \%)$ mempunyai anak yang perkembangannya meragukan, ibu yang bekerja sebagai swasta/pedagang setengahnya (50\%) mempunyai anak yang perkembangannya sesuai dan meragukan sedangkan ibu yang bekerja sabagai pegawai negeri seluruhnya (100\%) mempunyai anak yang perkembangannya sesuai.

Hal ini karena responden yang bekerja sebagai petani dan pedagang sibuk dalam pekerjaannya sehingga kurang dalam pemberian pola asuh pada anaknya, lain halnya ibu yang bekerja sebagai pegawai negeri memiliki pendidikan yang baik, sehinggah pengetahuan responden tentang pola asuh juga baik. Orang tua sangat berperan dalam pengasuhan anak, mulai dari pemberian nutrisi yang lengkap dan seimbang, hingga 
membantu anak mencapai perkembangan yang optimal (Santrock, 2010).

Berdasarkan penelitian yang dilakukan oleh Lisa Ulfa Farrah (2012) yang berjudul Hubungan Pemberian ASI Eksklusif Dengan Perkembangan Motorik Kasar Balita Di Kelurahan Brontokusuman Kecamatan Mergangsan Yogyakarta $(\rho=0,000)$ yang berarti bahwa ada Hubungan Pemberian ASI Eksklusif Dengan Perkembangan Motorik Kasar Balita Di Kelurahan Brontokusuman Kecamatan Mergangsan Yogyakarta.

Dan penelitian oleh Siti Dewi Rahmawati dan Septiarini Pujiastuti (2012) yang berjudul Hubunga pola asuh dengan perkembangan anak usia prasekolah di TK Kartika X-9 Cimahi 2012 yang mengatakan bahwa ada Hubunga pola asuh dengan perkembangan anak usia prasekolah di TK Kartika X-9 Cimahi $2012(\rho=0,013)$. Hal ini menunjukkan bahwa perkembangan motorik kasar balita dipengaruhi oleh pemberian ASI eksklusif dan perkembangan anak juga dipengaruhi oleh pola asuh orang tua.

Berdasarkan hasil yang diperoleh dilapangan sebagian besar $(51,4 \%)$ responden memiliki perkembangan yang sesuai, hal tersebut perlu ditingkatkan agar perkembangan anak dimasa depan lebih baik dari sebelumnya. Dan juga dengan adanya rangsangan dari lingkungan sekitar dan keseriusan orang tua dalam memberikan arahan dan bimbingan pada anak dalam bentuk apapun amat dibutuhkan karena dapat merangsangan perkembangan intelektual dimana dengan melaksanakan eksplorasi dan manipulasi terhadap alat permainan anak belajar memecahkan masalah.

\section{Hubungan Status Gizi Dengan PerkembanganAnak Usia Toodler (1 - 3 Tahun)}

Dari hasil uji statistik didapatkan signifikasi uji $(\rho) 0,664$ yang berarti $\rho>\alpha(\alpha=$ 0,05) sehingga $\mathrm{H}_{1}$ ditolak atau $\mathrm{H}_{0}$ diterima yaitu tidak ada Hubungan Status Gizi dengan Perkembangan di Desa Bangkal Kecamatan Kota Kabupaten Sumenep Tahun 2019.

Hal ini tidak sesuai dengan teori yang disampikan oleh Mahendra dan Saputra (2016) menyatakan perkembangan motorik sangat dipengaruhi oleh gizi, status kesehatan, dan perlakuan gerak yang sesuai dengan masa perkembangannya. Status gizi yang kurang akan menghambat laju perkembangan yang dialami individu, akibatnya proporsi struktur tubuh menjadi tidak sesuai dengan usianya yang pada akhirnya semua itu akan berimplikasi pada perkembangan aspek lain.

Dalam pertumbuhan dan perkembangan anak memerlukan zat gizi agar proses pertumbuhan dan perkembangan berjalan dengan baik. Zat-zat gizi yang dikonsumi batita akan berpengaruh pada status gizi batita. Perbedaan status gizi batita memiliki pengaruh yang berbeda pada setiap perkembangan anak, apabila gizi seimbang yang dikomsumsi tidak terpenuhi, pencapaian pertumbuhan dan perkembangan anak terutama perkembangan motorik yang baik akan terhambat.

Berdasarkan pada hasil penelitian dilapangan tidak mendapatkan Hubungan Status Gizi dengan Perkembangan Anak Usia Toodler (1-3 tahun) di Desa Bangkal Kecamatan Kota, sama seperti penelitian yang diteliti oleh Dr. Glady Gunawan, Sp.A (2010) yang meneliti mengenai hubungan status gizi dengan perkembangan anak usia 1-2 tahun di Kabupaten Bandung. Hasil penelitian menunjukkan tidak ada hubungan antara hubungan status gizi dengan perkembangan anak usia 1-2 tahun. Pada usia 1-2 tahun, sebagian besar anak masih mendapatkan perhatian dari ibunya mengenai makanan dan masih meminum ASI sehingga perkembangan termasuk dalam kategori meragukan, belum ada perkembangan dengan kategori penyimpangan. Pada penelitian di Porong Sidoarjo oleh Proboningsih dkk, juga tidak mendapatkan hubungan antara status gizi dengan perkembangan anak $(\rho=0,09)$.

Status gizi batita tidak selamanya mempengaruhi perkembangan. Ada faktor lain yang mungkin dapat mempengaruhi perkembangan batita seperti faktor lingkungan (prenatal, kelahiran, pascanatal yang terdiri dari gizi meliputi status gizi, pemberian ASI, nutrisi, penyakit kronis, lingkungan fisik dan kimia, psikologis, endokrin, sosial ekonomi, lingkungan pengasuh, stimulasi, obat-obat). Menurut hasil penelitian Ulfa Farrah Lisa (2012) yang berjudul Hubungan Pemberian ASI Eksklusif Dengan Perkembangan Motorik Kasar Balita Di Kelurahan Brontokusuman Kecamatan Mergangsan Yogyakarta diketahui $(\rho=0,000)$ yang berarti ada hubungan yang bermakna antara pemberian ASI eksklusif dengan perkembangan motorik kasar balita. 
Faktor stimulasi juga memegang peranan penting dalam tumbuh kembang anak. Anak yang mendapat stimulasi terarah dan teratur akan lebih cepat berkembang dibandingkan dengan anak yang tidak/kurang mendapatkan stimulasi

Hampir setengahnya dari jumlah responden yang memiliki status gizi kurus mengalami perkembangan yang sesuai dan sebagian besar responden yang memiliki status gizi normal mengalami perkembangan yang sesuai dan meragukan, hal tersebut menggambarkan bahwa status gizi anak tidak memberikan dampak langsung terhadap perkembangan anak, ada faktor lain yang berperan penting dalam perkembangan seperti yang paling penting adalah stimulasi.

Saat ini diperlukan upaya menyeluruh untuk menjaga tumbuh kembang anak sedini mungkin bahkan sejak dalam kandungan sampai usia lima tahun. Pemberian stimulasi diperlukan sesuai usia anak. Meningkatkan peran serta ibu untuk selalu mendapat informasi mengenai status gizi dan perkembangan anak, sehingga apabila terjadi kecurigaan adanya gangguan atau keterlambatan perkembangan dapat di deteksi secara dini. Perlunya penelitian lebih lanjut mengenai perkembangan anak terutama saat anak masih dibawah 3 tahun.

\section{PENUTUP}

\section{Kesimpulan}

1) Anak usia Toodler (1-3 tahun) di Desa Bangkal Kecamatan Kota Sumenep sebagian besar memiliki status gizi normal.

2) Anak usia Toodler (1-3 tahun) di Desa Bangkal Kecamatan Kota Sumenep hampir setengahnya memiliki perkembangan yang sesuai.

3) Status gizi dengan perkembangan anak usia Toodler (1-3 tahun) di Desa Bangkal Kecamatan Kota Sumenep tidak memiliki korelasi.

\section{Saran}

1) Bagi Peneliti

Penelitian ini hanya mengukur status gizi dengan perkembangan anak usia Toodler. Peneliti lain hendaknya lebih mengembangkan penelitian faktor lain yang lebih mempengaruhi perkembangan anak selain status gizi dengan mengutamakan uji validitas dan reabilitas sebelum melakukan pengumpulan data.

2) Bagi Profesi Kebidanan

Bagi ilmu kebidanan agar bahan ini dapat dijadikan sebagai masukan tentang status gizi pada anak.

3) Bagi Institusi Pendidikan

Hasil penelitian ini selanjutnya dapat digunakan sebagai acuan penelitian berikutnya dan dapat dikembangkan lebih luas lagi. Untuk itu diharapkan adanya penelitian lebih lanjut tentang faktor lain yang mempengaruhi terjadinya mempengaruhi perkembangan anak.

4) Bagi Masyarakat / Orang Tua

Jika orang tua memperhatikan keadaan gizi anak dengan baik, maka dapat membantu anak mencapai pertumbuhan dan perkembangan secara optimal. 


\section{DAFTAR PUSTAKA}

1. Hidayat,A.Aziz Alimul.2010.Ilmu Kesehatan Anak.Jakarta:Salemba Medika

2. KIA-KR. 2009. Maternal and Neonatal Child Health.Yogyakarta:Minat Utama KIA-KESPRO Program S2 IKM FK UGM.

3. Nursalam,dkk.2108.Asuhan

Keperawatan Bayi dan Anak.Jakarta:Salemba Medika

4. Purwanti, HS.2010.Konsep Penerapan ASI Eksklusif.Jakarta:EGC

5. Roesli,U.2010.SDM Mendatang Tergantung ASI Eksklusif.From Http://WWW.gizi.com

6. Selasi. 2009. Menyusui Langkah Perlindungan.Jakarta:Sentra Laktasi Indonesia.

7. Yulia.2007.Buku Pintar Bunda tentang Si Kecil.Jakarta Pusat:PT Setia Purna Inves 
